\title{
Middle Stratospheric Polar Vortex Ozone Budget during the Warming Arctic Winter, 2002-2003
}

\author{
LIU Yi ${ }^{1}$ (刘 毅), LIU Chuanxi*1,2 (刘传熙), Xuexi TIE ${ }^{3}$ (铁学熙), and GAO Shouting ${ }^{4}$ (高守亭) \\ ${ }^{1}$ Key Laboratory of Middle Atmosphere and Global Environment Observation, \\ Institute of Atmospheric Physics, Chinese Academy of Sciences, Beijing 100029 \\ ${ }^{2}$ Graduate University of Chinese Academy of Sciences, Beijing 100049 \\ ${ }^{3}$ National Center for Atmospheric Research, Boulder, Colorado, USA \\ ${ }^{4}$ Laboratory of Cloud Precipitation Physics and Severe Storms, \\ Institute of Atmospheric Physics, Chinese Academy of Sciences, Beijing 100029
}

(Received 12 June 2010; revised 10 October 2010)

\begin{abstract}
The ozone budget inside the middle stratospheric polar vortex (24-36 km) during the 2002-2003 Arctic winter is studied by analyzing Michelson Interferometer for Passive Atmospheric Sounding (MIPAS) satellite data. A comprehensive global chemical transport model (Model for Ozone and Related Chemical Tracers, MOZART-3) is used to analyze the observed variation in polar vortex ozone during the stratospheric sudden warming (SSW) events. Both MIPAS measurement and MOZART-3 calculation show that a pronounced increase (26-28 DU) in the polar vortex ozone due to the SSW events. Due to the weakening of the polar vortex, the exchange of ozone mass across the edge of the polar vortex increases substantially and amounts to about $3.0 \times 10^{7} \mathrm{~kg}$ according to MOZART-3 calculation. The enhanced downward transport offsets about $80 \%$ of polar vortex ozone mass increase by horizontal transport. A "passive ozone" experiment shows that only $\sim 55 \%$ of the vertical ozone mass flux in February and March can be attributed to the variation in vertical transport. It is also shown that the enhanced downward ozone above $\sim 32 \mathrm{~km}$ should be attributed to the springtime photochemical ozone production. Due to the increase of air temperature, the $\mathrm{NO}_{x}$ reaction rate increases by $40 \%-80 \%$ during the SSW events. As a result, $\mathrm{NO}_{x}$ catalytic cycle causes another $44 \%$ decrease in polar vortex ozone compared to the net ozone changes due to dynamical transport. It is also shown that the largest change in polar vortex ozone is due to horizontal advection by planetary waves in January 2003.
\end{abstract}

Key words: stratospheric sudden warming, planetary wave, MIPAS, MOZART-3 model, ozone depletion

Citation: Liu, Y., C. X. Liu, X. X. Tie, and S. T. Gao, 2011: Middle stratospheric polar vortex ozone budget during the warming arctic winter, 2002-2003. Adv. Atmos. Sci., 28(5), 985-996, doi: 10.1007/s00376-0100045-9.

\section{Introduction}

Stratospheric ozone protects Earth's life from overexposure to the harmful solar UV radiation. The variation in polar column ozone is significant for both the Earth UV shield and the monitoring of future stratospheric ozone recovery and climate changes. Since the discovery of the Antarctic ozone hole during austral spring (Farman et al., 1985), considerable attention has been paid to formation and destruction of the stratospheric ozone layer, such as impacts of heterogeneous reactions of halogen compounds, eruption of volcanoes, and formation of polar clouds on stratospheric ozone (Solomon, 1990; Brasseur et al., 1990; Tie and Brasseur, 1995, 1996.)

In past two decades, another important finding related to the stratospheric ozone layer is that the variability of stratospheric temperature has an im-

\footnotetext{
*Corresponding Author: LIU Chuanxi, tenkeiliu@gmail.com

(C) China National Committee for International Association of Meteorology and Atmospheric Sciences (IAMAS), Institute of Atmospheric Physics (IAP) and Science Press and Springer-Verlag Berlin Heidelberg 2011
} 
portant effect on stratospheric ozone concentrations. Manney et al. (1994) showed that ozone concentrations were lower during cold Arctic winters. Further studies showed that the processes controlling the wintertime Arctic stratospheric ozone is very complicated (Manney et al., 2003; Rex et al., 2004) and varies dramatically from year to year as a result of the high interannual variability in stratospheric dynamics (e.g., Fusco and Salby, 1999). Extreme planetary disturbances during northern winters sometimes lead to stratospheric sudden warming (SSW) events (Scherhag, 1952). During major SSW events, the polar vortex is strongly perturbed by the planetary wave breaking. As a result, filaments of high potential vorticity (PV) air are stripped off the edge of the main vortex and are mixed with the surrounding low $\mathrm{PV}$ air (McIntyre and Palmer, 1983). In the 1990s, only a few satellite-based measurements, such as the Polar Ozone and Aerosol Measurement experiment (POAM II) (Randall et al., 1995) and instruments onboard the Upper Atmosphere Research Satellite (UARS) (e.g., Froidevaux et al., 1994), could observe the high northern latitudes. That is why most of early studies on wintertime ozone in the northern hemisphere were confined southward of $60^{\circ} \mathrm{N}$ (e.g., Zou et al., 2005).

Recent observations from satellite-borne instruments operated by the National Aeronautics and Space Administration (NASA), European Space Agency (ESA), and Canadian Space Agency (CSA) provide the unprecedented opportunity to study polar stratospheric ozone and other trace gases during the polar winter season. The Arctic winter 2002-2003 is the first northern winter when a series of high-resolution satellite observations with global coverage begins to be available for polar stratospheric studies. Additionally, a number of aircraft and ground field campaigns were also performed. These observational studies show clear evidence that the early 2002-2003 Arctic winter was unusually cold and experienced significant ozone loss (Tilmes et al., 2003; Streibel et al., 2006). Liu et al. (2009a, c) analyzed MIPAS measurements and MOZART-3 simulations for recent SSW events (20022003 and 2003-2004) and showed that stratospheric dynamics had important impacts on the distribution of middle stratospheric ozone and long-lived trace gas $\left(\mathrm{N}_{2} \mathrm{O}\right)$. They also reported a pronounced enhancement in downward ozone flux in the polar region $\left(60^{\circ}-90^{\circ} \mathrm{N}\right)$ during the above two winters. However, the detailed ozone budget inside the polar vortex was not intensively studied due to these SSW events and needs to be quantified. In addition, little attention is paid to middle stratospheric chemistry during these SSW events. Recently, a few studies have suggested that stratospheric $\mathrm{NO}_{x}$ chemistry plays important roles in con- trolling polar ozone concentrations during SSW events (e.g., Konopka et al., 2007; Flury et al., 2009). In this study, we use the MOZART-3 model to quantify the respective contribution of dynamics and chemistry processes to the ozone budget inside the middle stratospheric polar vortex. The $\mathrm{Cl}_{y}$ and $\mathrm{Br}_{y}$ chemistry, which dominates the polar ozone loss in the lower stratosphere, is not considered in this study.

This paper is organized in the following way. section 2 briefly introduces the satellite observations and the chemical transport model. Section 3.1 compares the model result with satellite measurements and analyzes the wintertime ozone column in the polar vortex between 24 and $36 \mathrm{~km}$. In section 3.2, the dynamical (horizontal and vertical transports) and chemical contributions are quantified to study the ozone budget inside the polar vortex. The main results are summarized and highlighted in section 4 .

\section{Description of data and model}

\section{$2.1 \quad M I P A S$ data}

The Michelson Interferometer for Passive Atmospheric Sounding (MIPAS) is a limb-scanning Fourier transform infrared spectrometer (FTIR) on board the European Environmental Satellite (ENVISAT). Currently, the level-2 operational data of MIPAS is provided by ESA and includes the temperature and the concentrations of $\mathrm{O}_{3}, \mathrm{NO}_{2}$, and a series of long-lived trace gases (e.g., $\mathrm{N}_{2} \mathrm{O}, \mathrm{CH}_{4}$, etc). In its original nominal measurement mode, MIPAS scanned the Earth limb at 17 tangent altitudes of $6,9, \ldots, 39,42,47,52$, 60 , and $68 \mathrm{~km}$. The vertical resolution is $3 \mathrm{~km}$ for the 13 lowermost tangent altitudes and increases to $8 \mathrm{~km}$ at the upper end of the limb scan. Raspollini et al. (2006) provided detailed descriptions of MIPAS measurements. The validation of the retrieved ozone profiles from MIPAS level-2 operational products were analyzed by Cortesi et al. (2007). Their studies showed that MIPAS ozone profiles have the mean relative difference of $\pm 10 \%$ with the individual correlative data sets in the stratosphere. $\mathrm{N}_{2} \mathrm{O}$ partial columns from MIPAS show good agreement with ground-based FTIR observations. The biases of the data are below $5 \%$ for all the stations. The standard deviations are below $7 \%$ for the three midlatitude stations, and below $10 \%$ for the high-latitude ones (Vigouroux et al., 2007). In this study, the retrieved ozone and $\mathrm{N}_{2} \mathrm{O}$ profiles are regridded onto $73 \times 72$ (about $2.5^{\circ}$ lat $\times 5^{\circ}$ lon) horizontal grid meshes as in a previous study (Liu et al., 2009c). 


\subsection{MOZART-3 model}

In this study, we use the middle atmospheric version of the three-dimensional Model for Ozone And Related chemical Tracers, version 3 (MOZART-3), which is an extension to the middle atmosphere of its former tropospheric versions (Brasseur et al., 1998; Hauglustaine et al., 1998; Horowitz et al., 2003). The detailed model description and evaluation were given by Kinnison et al. (2007). In addition to basic dynamics (advection, convective transport, boundary layer mixing, and dry/wet deposition), the model emphasizes detailed physical and chemical processes in the middle atmosphere, such as vertical mixing associated with gravity wave breaking in the upper stratosphere and mesosphere, molecular diffusion of constituents above $80 \mathrm{~km}$, photochemical reactions associated with halogen compounds, stratospheric heterogeneous processes involving sulfate aerosols and polar stratospheric clouds, photolysis at short wavelengths ( $>120 \mathrm{~nm}$ ), and auroral contribution to the chemical budget. The trace gas emissions include surface emissions, the $\mathrm{NO}_{x}$ and $\mathrm{CO}$ emissions from aircraft, and the $\mathrm{NO}_{x}$ source associated with lightning, which were described in previous studies (Horowitz et al., 2003; Gettelman et al., 2004; Park et al., 2004). Previous studies show that the MOZART-3 model is suitable to represent stratosphere-troposphere exchange processes (Gettelman et al., 2004; Park et al., 2004) and ozone concentrations in the extratropical tropopause region (Pan et al., 2007; Liu et al., 2009a). Recently, the MOZART-3 model has been used to study the impact of SSW events on the distribution of stratospheric ozone and $\mathrm{N}_{2} \mathrm{O}$ (Liu et al., 2009c). The results show that the modeling can represent the variation in the stratospheric chemistry observed by the MIPAS satellite measurements during the 2002-2003 and 20032004 SSW events well. At present, the MOZART-3 model has been incorporated into the Whole Atmosphere Community Climate Model (WACCM) (Sassi et al., 2005; Garcia et al., 2007) at the National Center for Atmospheric Research and into the Hamburg Model for Neutral and Ionized Atmosphere (HAMMONIA) (Schmidt et al., 2006) at the Max Planck Institute for Meteorology.

Like other offline chemical transport models, MOZART-3 can perform at reasonable time steps and spatial resolutions. It can be driven by both analysis data and general circulation model output. Kinnison et al. (2007) examined the sensitivity of MOZART3 chemistry to different meteorological datasets. In our study, the model is driven with dynamical quantities taken from the ECMWF (European Centre for Medium-Range Weather Forecasts) operational analysis performed every 6 hours. The adopted model con- figuration includes 96 Gaussian grid cells in latitude and 192 cells equidistant in longitude, which represents a horizontal resolution of approximately $1.875^{\circ}$ in both latitude and longitude. In the vertical domain, the model has 60 levels from the surface to approximately $65 \mathrm{~km}$, with vertical resolution about $0.5 \mathrm{~km}$ in the middle troposphere, $1 \mathrm{~km}$ in the UTLS region, and $1.5 \mathrm{~km}$ in other regions of the stratosphere.

In the present study, the initial condition for chemical compounds is the same as that in the previous study by Liu et al. (2009c). The seasonal simulation starts on 1 December 2002 and proceeds until 1 April 2003. Since no chemical data assimilation is performed to initiate the chemistry, the calculated result before 15 December 2002 is considered as the spinup of the model. Only the simulation after 15 December 2002 is used in our analysis. In addition, as indicated by both numerical (e.g., Solomon et al., 1982) and observational (e.g., Randall et al., 2005) studies, the polar ozone concentrations in the middle and upper stratosphere are sensitive to the upper boundary condition of nitrogen oxides $\left(\mathrm{NO}_{x}=\mathrm{NO}+\mathrm{NO}_{2}\right)$ during polar winters. In MOZART-3, the original setup of the $\mathrm{NO}_{x}$ upper boundary condition (UBC) is derived from the monthly climatology of the Thermosphere Ionosphere Mesosphere Electrodynamic General Circulation Model (TIME-GCM) (Robe and Ridley, 1994), which is an upper-atmospheric component of the WACCM system (see Garcia et al., 2007). The MOZART-3 $\mathrm{NO}_{x}$ UBC is much higher than the MIPAS measurements for the value in 2002-2003 winter (not shown). As a result, it leads to overestimation of wintertime polar ozone destruction in the middle and upper stratosphere (personal communication with Guy Brasseur and Douglass Kinnison at NCAR). In this study, the monthly mean $\mathrm{NO}_{x} \mathrm{UBC}$ in high northern latitudes (northward of $60^{\circ} \mathrm{N}$ ) is derived from the measured $\mathrm{NO}_{2}$ concentrations from the gridded MIPAS data. With this modification of the model condition, the simulated polar stratospheric ozone above $30 \mathrm{~km}$ is improved (not shown) and is more consistent with measured results (see section 3.1). In order to separate the photochemical ozone production from vertical ozone transport during the springtime return of sunshine, a "passive ozone" run is also performed and compared with the "reactive ozone" run (see section 3.2).

\section{Results}

\section{$3.1 \quad$ Measured and calculated $\mathrm{O}_{3}$ and $\mathrm{N}_{2} \mathrm{O}$}

The early 2002-2003 Arctic winter was cold and experienced significant ozone loss in the lower part of the polar vortex (Tilmes et al., 2003; Streibel et al., 

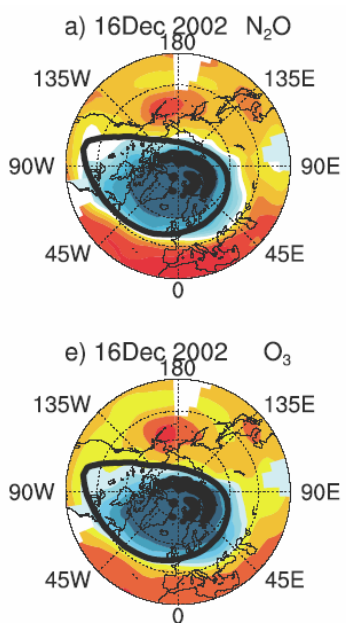
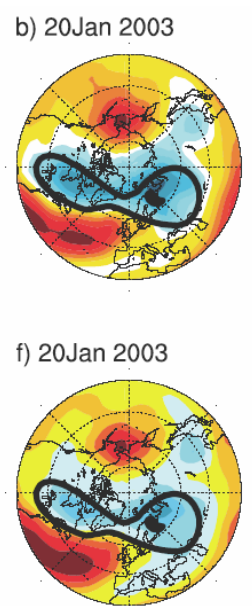

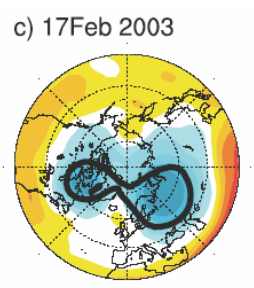

g) $17 \mathrm{Feb} 2003$

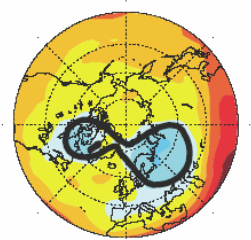

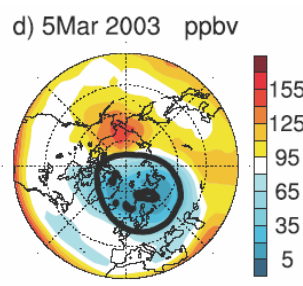

h) 5 Mar 2003 ppmv

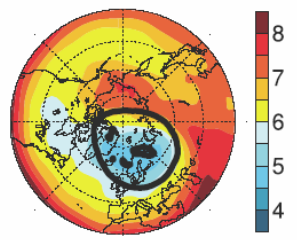

Fig. 1. Measured (MIPAS) distribution of $\mathrm{N}_{2} \mathrm{O}$ (upper panels, unit: ppbv) and ozone mixing ratios (lower panels, units: ppmv) at $30 \mathrm{~km}$ during the Arctic winter 2002-2003, (a and e) on 16 December 2002; (b and f) on 20 January 2003; (c and g) on 17 February 2003; (d and h) on 5 March 2003. The bold black modified PV isoline (35 PVU) represents the edge of polar vortex.

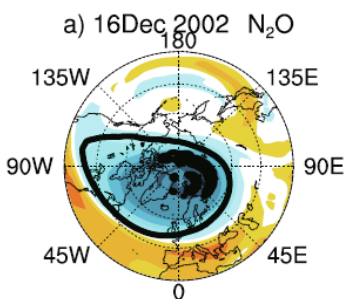

e) $16 \mathrm{Dec}_{1} 2 \mathrm{OO} \quad \mathrm{O}_{3}$

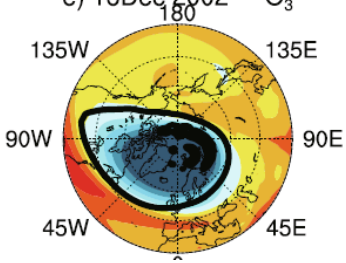

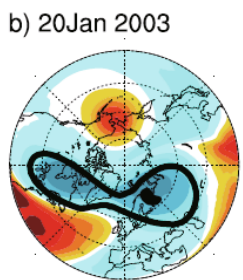

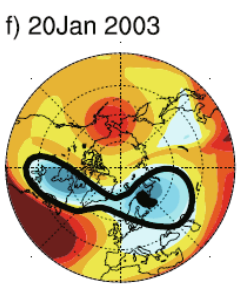

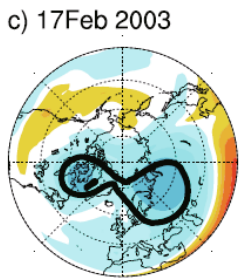

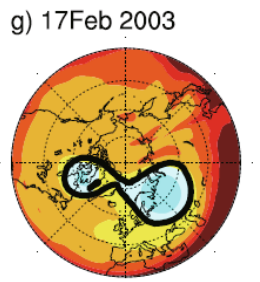

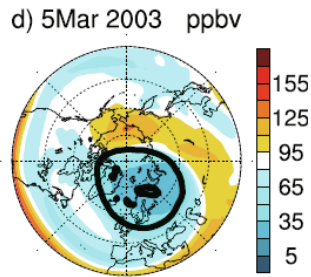

h) 5 Mar 2003 ppmv

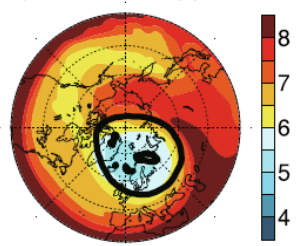

Fig. 2. Same as Fig. 1, but for results from MOZART-3 calculation.

2006). In this study, the ozone variation in the middle stratospheric polar vortex is examined. A major SSW event took place in late January 2003, which was followed by two weaker SSW events in mid-February and early March (Manney et al., 2005). Figure 1 shows the measured (MIPAS) distribution of $\mathrm{N}_{2} \mathrm{O}$ and ozone mixing ratios in the middle stratosphere (at $30 \mathrm{~km}$ ) in early winter (on 16 December 2002) and during the three SSW events (on 20 January, 17 February, and 20 March 2003). The polar vortex edge is marked with the solid modified PV contour (35 PVU). The definition of the modified PV (referenced to the $475 \mathrm{~K}$ potential temperature level) is provided by Lait (1994). It is shown that the polar vortex plays a dominant role in controlling the distribution of both trace gases in the northern hemisphere. Due to the SSW events, the polar vortex was split (on 20 January and 17 February 2003) and diffused (on 5 March 2003). The vortex remnants were gradually diluted with air mass of middle latitudes. As a result, the gradients of $\mathrm{N}_{2} \mathrm{O}$ and ozone in middle and high latitudes were prominently smoothed (compare panel a with c and compare panel e with $\mathrm{g})$.

In order to use MOZART-3 to study the ozone budget during the SSW events, the performance of the model is evaluated and compared to measured results. Figure 2 shows the horizontal distribution of calculated ozone and $\mathrm{N}_{2} \mathrm{O}$ concentrations by MOZART-3. It is shown that the MOZART-3 model can generally represent the variation in distribution of both ozone 

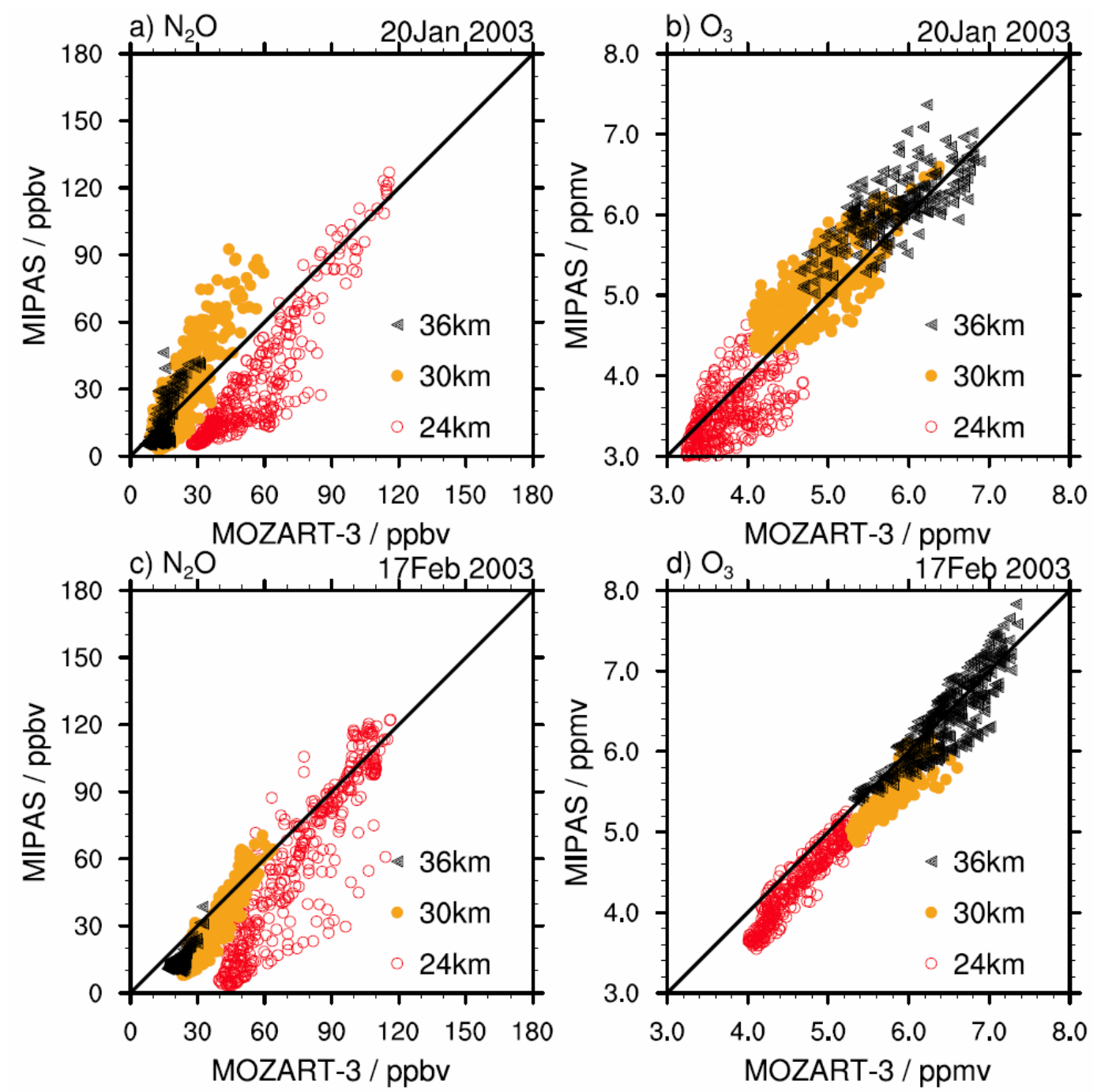

Fig. 3. Comparison of stratospheric trace gases $\left(\mathrm{N}_{2} \mathrm{O}\right.$ and ozone) from MOZART-3 simulation with MIPAS measurements at 24 (red open dots), 30 (yellow solid dots), and $36 \mathrm{~km}$ (black triangles) inside the polar vortex on 20 January (upper panels) and 17 February (lower panels) 2003.

and $\mathrm{N}_{2} \mathrm{O}$ concentrations during the SSW events. A similar comparison was performed in our previous study (Liu et al., 2009c). The point-to-point comparison on 20 January and 17 February 2003, as shown in Fig. 3, suggests that the calculated ozone concentration is generally consistent with the MIPAS measurement (see panels $\mathrm{b}$ and $\mathrm{d}$ ). However, there are pronounced differences between the simulation and measurement of $\mathrm{N}_{2} \mathrm{O}$ concentration inside the polar vortex (see panels $\mathrm{a}$ and $\mathrm{b}$ ). These differences could result from the bias in model's initial condition and insufficiency of the model's mixing scheme near the vortexedge and vortex-core regions. For example, in the vortex-core region on 20 January 2003 (with the mixing ratio $<30 \mathrm{ppbv}$ at $30 \mathrm{~km}$ ), the $\mathrm{N}_{2} \mathrm{O}$ concentration is slightly overestimated by the MOZART-3 calcula- tion (see the orange dots in Fig. 3a). Similarly, in the vortex-edge region (with the mixing ratio $>30 \mathrm{ppbv}$ at $30 \mathrm{~km}$ ), the $\mathrm{N}_{2} \mathrm{O}$ concentration is prominently overestimated in the model simulation. These features are also noticeable in the horizontal distribution of $\mathrm{N}_{2} \mathrm{O}$ concentration at $30 \mathrm{~km}$ (compare Figs. $1 \mathrm{~b}$ and $2 \mathrm{~b}$ ) and exist at other altitudes (see Figs. 3a and 3d).

Figure 4 further compares the monthly average volume mixing ratios of polar stratospheric $\mathrm{N}_{2} \mathrm{O}$ and ozone (northward of $60^{\circ} \mathrm{N}$ ) from the measurement (MIPAS) with the calculation (MOZART-3) in January and February 2003. As shown in Fig. 2, the MOZART-3 result is fairly consistent with the measured $\mathrm{N}_{2} \mathrm{O}$ and ozone concentrations in the stratosphere (at altitudes of 24,30 , and $36 \mathrm{~km}$ ). The correlation coefficients between the model and measure- 

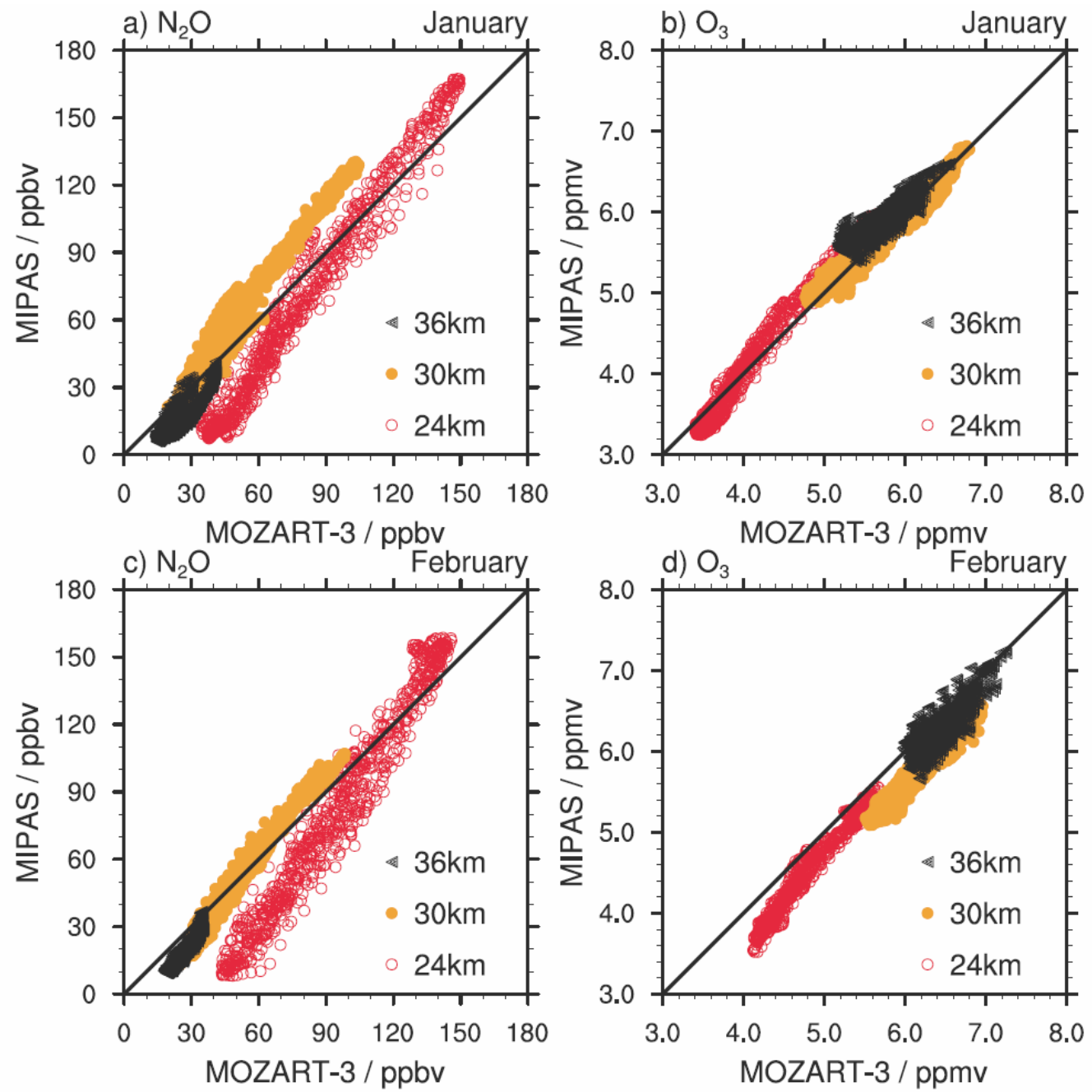

Fig. 4. Same as Fig. 3, but for results northward of $60^{\circ} \mathrm{N}$ in January (upper panels) and February (lower panels) 2003.

ment range from 0.88 to 0.99 . There also exist some discrepancies between calculation and measurement as shown in Fig. 4. Similar to the results in Fig. 3, the calculated $\mathrm{N}_{2} \mathrm{O}$ concentration is underestimated when its concentration is higher, while overestimated when concentration is lower. As explained in the above text, the model's biases in both the initial condition and mixing scheme could be the principal cause of these discrepancies. Compared to $\mathrm{N}_{2} \mathrm{O}$ concentration, there is much less bias in the calculated ozone concentrations. As is shown in Fig. 4 (panels b and d), there is no obvious bias for the calculated ozone in January, but the calculated ozone in February is consistently overestimated by $0.2-0.4$ ppmv compared to the measured value. As a chemically active compound, the discrepancy of ozone is due to both the biases of dynamics and chemistry in the model.

Figure 5 shows the analyzed temperature
(ECMWF) and measured (MIPAS) and calculated (MOZART) ozone and $\mathrm{N}_{2} \mathrm{O}$ mixing ratios from 15 December 2002 to 1 April 2003. All variables are averaged inside the polar vortex (35 modified PV contour) at each altitude (with area weighted). The eddy heat flux at $100 \mathrm{hPa}$ (average between $45^{\circ} \mathrm{N}$ and $75^{\circ} \mathrm{N}$ ) is also calculated, which can be used as an indicator for the planetary wave activity (see panel f). As shown in Fig. 5, the wave activity is highly correlated to the warming of the middle stratospheric polar vortex (compare panel a with panel $\mathrm{f}$ ). This signal is much clearer if you compare Fig. 3f with Fig. 5a, which is the temperature variation in early 2003 relative to the 15-31 December 2002 average. For example, the first peak of wave activity occurs after 15 January 2003 (see Fig. 5f), while the middle stratospheric polar vortex begins to warm up on around 20 January 2003. Another example is that the second peak takes place 


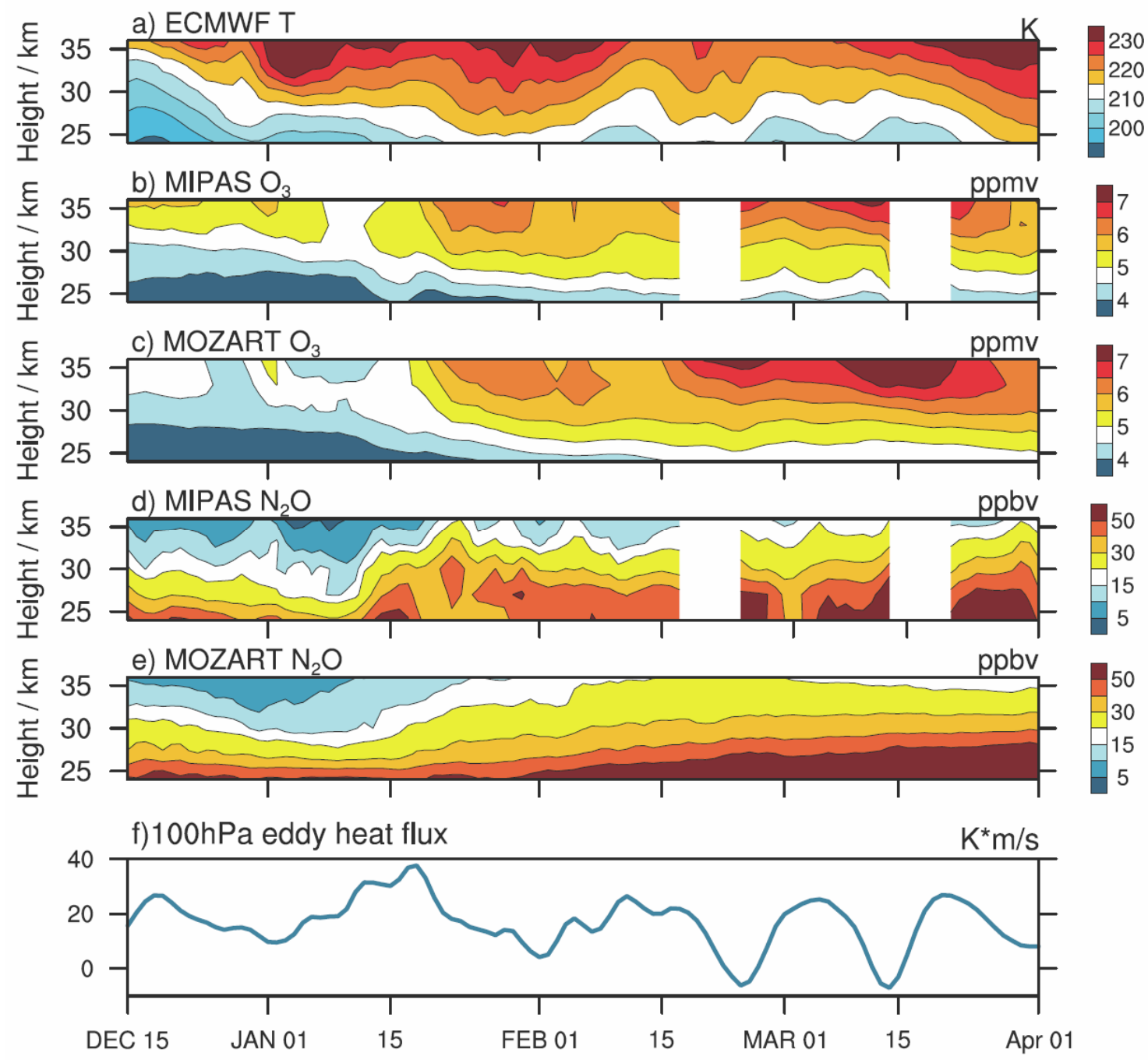

Fig. 5. Evolution of temperature (ECMWF), and measured (MIPAS) and calculated (MOZART-3) ozone and $\mathrm{N}_{2} \mathrm{O}$ mixing ratios inside the polar vortex (average with area weighted) between 24 and $36 \mathrm{~km}$ from 15 December 2002 to 1 April 2003: (a) temperature (units: K); (b) ozone (units: ppmv) from MIPAS; (c) ozone from MOZART-3; (d) $\mathrm{N}_{2} \mathrm{O}$ (units: ppbv) from MIPAS; (e) $\mathrm{N}_{2} \mathrm{O}$ from MOZART-3; (f) the eddy heat flux $\left(\mathrm{K} \mathrm{m} \mathrm{s}^{-1}\right)$ at $100 \mathrm{hPa}$ (average between $45^{\circ} \mathrm{N}$ and $\left.75^{\circ} \mathrm{N}\right)$, representing the planetary wave activity.

on 10 February 2003 (see Fig. 5f), while the polar vortex warms again on about 15 February 2003. Both observations (panels b and d) and simulations (panels $c$ and e) suggest that there are pronounced increases in ozone and $\mathrm{N}_{2} \mathrm{O}$ concentrations during the SSW events (during late January, mid-February, and early March 2003). As suggested in previous studies (e.g., Matsuno, 1971), the strongly developed planetary disturbances from the troposphere lead to pronounced warming in the polar stratosphere within the synoptic time scale. As a result, warm air with higher concentrations of ozone and long-lived trace gases $\left(\mathrm{N}_{2} \mathrm{O}\right.$ in the present study) is transported northward and dilutes the cold vortex remnants. Evolution of the trace gases (panels b through e) also shows that an increase of concentrations in the upper layers proceeds down into the lower layers. This feature was highlighted by Liu et al. (2009b) and was attributed to the downward progress of the stratospheric warming and the vortex disturbances.

Figure 6 shows the averaged column (24-36 km) $\mathrm{N}_{2} \mathrm{O}$ and ozone in the polar vortex from both MIPAS and MOZART-3 throughout the SSW event. It shows that the variations in column ozone and $\mathrm{N}_{2} \mathrm{O}$ are very similar, suggesting the dynamical processes play important roles for the variations of $\mathrm{N}_{2} \mathrm{O}$ and ozone in the polar vortex. However, it is also noted that the increase of $\mathrm{N}_{2} \mathrm{O}$ is larger than that of ozone, especially 

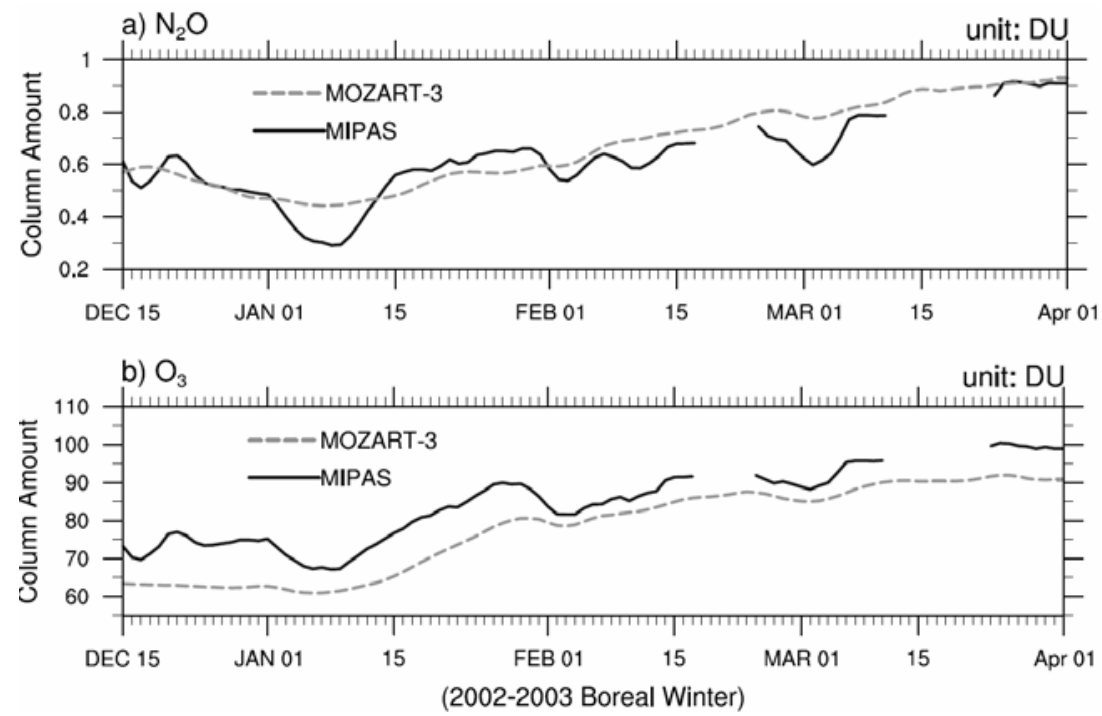

Fig. 6. Column (units: DU) $\mathrm{N}_{2} \mathrm{O}$ and ozone averaged in the polar vortex (24-36 km) from both MIPAS and MOZART-3 throughout the winter.

during March 2003, suggesting that chemical processes are also important in controlling the ozone variation. The evolutions of column $\mathrm{N}_{2} \mathrm{O}$ and ozone calculated by MOZART-3 are generally consistent with the MIPAS measurements, but the calculated variations are considerably smoothed. This result implies that there might be some biases in model's transport schemes and that the model's horizontal resolution might be too coarse to represent the fine features in the present study (see also Figs. 4 and 5). Additionally, the calculated column ozone is underestimated by about 5-10 DU throughout the winter, suggesting there are some biases in the model's chemistry. In order to quantify the general effect of the atmospheric dynamics and chemistry, we calculate the increases in column $\mathrm{N}_{2} \mathrm{O}$ and ozone during early winter (15-31 December 2002) and early spring (15-31 March 2003) (see Table 1). The results in Table 1 suggest that (1) the calculated column ozone and $\mathrm{N}_{2} \mathrm{O}$ concentrations are generally consistent with measured result, except that the column ozone is about $10 \%-15 \%$ lower than the measured value. (2) The calculated trends from late December 2002 to late March 2003 are also generally consistent with the measured trends. For example, the increases in column $\mathrm{N}_{2} \mathrm{O}$ are 0.35 and $0.36 \mathrm{DU}$ for the measurement and calculation, respectively. The increases in column ozone are 26 and 28 DU for measurement and calculation, respectively. (3) The increment of $\mathrm{N}_{2} \mathrm{O}$ is considerably larger than that of ozone. For example, the measured increase in column $\mathrm{N}_{2} \mathrm{O}$ is $64 \%$. By contrast, the measured increase in column ozone is only $35 \%$. The large difference between the increases of column ozone and $\mathrm{N}_{2} \mathrm{O}$ implies that ozone chem- istry may play an important role, especially during the SSW events in late winter and early spring. The detailed ozone budget analysis can give some insights into the importance of ozone chemistry as shown in the following text.

\subsection{Polar vortex ozone budget}

In order to study the individual contributions from both dynamical and chemical processes to the ozone budget, we quantify the detailed ozone budget due to horizontal advection, vertical transport, and chemical reactions. The importance of temperature sensitivity of the $\mathrm{NO}_{x}$-catalytic cycle to the ozone depletion during the SSW events is also discussed.

Figure 7 (panel a) shows the evolution of temperature increase (averaged in the polar vortex) relative to the December 2002 average. It shows that the temperature increases by 10 to $18 \mathrm{~K}$ during the SSW events (in late January, mid-February, and early March 2003). These major warming events are closely related to the upward-propagating planetary waves from the troposphere (compare Fig. 7a with Fig. 5f) and poleward transport from the lower latitudes. With the disturbances of the polar vortex, the horizontal advection of ozone-rich air is enhanced (compare Fig. $7 \mathrm{~b}$ with Fig. 1). Table 2 compares polar vortex ozone fluxes during the SSW events with those in December 2002, when the polar vortex was less disturbed. As shown in Table 2, the horizontal ozone fluxes in January $\left(1.16 \times 10^{7} \mathrm{~kg}\right)$, February $\left(7.2 \times 10^{6}\right.$ $\mathrm{kg})$, and March $\left(1.12 \times 10^{7} \mathrm{~kg}\right)$ are $190 \%, 80 \%$, and $180 \%$ increased compared to the value in December $2002\left(4.0 \times 10^{6} \mathrm{~kg}\right)$. As a result, throughout the first 
Table 1. Comparison of measured (MIPAS) and calculated (MOZART-3) column (units: DU) $\mathrm{N}_{2} \mathrm{O}$ and ozone averaged in the polar vortex $(24-36 \mathrm{~km})$ during the 2002-2003 winter. Increments of the column $\mathrm{N}_{2} \mathrm{O}$ and ozone are derived by comparing the 15-31 December 2002 average and the 15-31 March 2003 average.

\begin{tabular}{lcccc}
\hline & \multicolumn{3}{c}{ Trace gases } \\
\cline { 2 - 5 } & $\mathrm{N}_{2} \mathrm{O}($ MIPAS) & $\mathrm{N}_{2} \mathrm{O}($ MOZART) & $\mathrm{O}_{3}$ (MIPAS) & $\mathrm{O}_{3}(\mathrm{MOZART})$ \\
\hline 15-31 Dec average & 0.55 & 0.54 & 73.8 & 62.8 \\
15-31 Mar average & 0.90 & 0.90 & 99.6 & 90.9 \\
Increment & 0.35 & 0.36 & 25.8 & 28.1 \\
Increase ratio & $64 \%$ & $67 \%$ & $35 \%$ & $45 \%$ \\
\hline
\end{tabular}

Table 2. Calculated variations of ozone mass (units: $10^{6} \mathrm{~kg}$ ) by dynamics (horizontal and vertical transport) and chemical loss inside the stratospheric polar vortex $(24-36 \mathrm{~km})$ during December 2002, and January, February, and March 2003.

\begin{tabular}{lcccr}
\hline & \multicolumn{3}{c}{$\mathrm{O}_{3}$ budget analysis } \\
\cline { 2 - 5 } & Horizontal & Vertical & Chemical & Net \\
\hline December & 4.0 & -3.5 & -0.2 & 0.3 \\
January & 11.6 & -7.7 & -0.7 & 3.2 \\
February & 7.2 & -5.8 & -1.7 & -0.3 \\
March & 11.2 & -11.0 & -0.1 & 0.1 \\
Total & 34.0 & -28.0 & -2.7 & 3.3 \\
\hline
\end{tabular}

three months in 2003 (January, February, and March), a total of $3.0 \times 10^{7} \mathrm{~kg}$ of ozone mass is transported into the polar vortex by horizontal advection. This increase in ozone mass is 6.5 times larger than the value $\left(4.0 \times 10^{6} \mathrm{~kg}\right)$ in December 2002 when the polar vortex is stable. The vertical advection within the polar vortex transports ozone-poor air in the upper stratosphere downward, diluting the ozone concentration inside the middle stratospheric vortex and causing decreases in polar vortex ozone mass during the SSW events. As shown in Table 2, the vertical ozone fluxes in January $\left(7.7 \times 10^{6} \mathrm{~kg}\right)$, February $\left(5.8 \times 10^{6} \mathrm{~kg}\right)$, and March $\left(1.1 \times 10^{7} \mathrm{~kg}\right)$ are about $120 \%, 60 \%$, and $210 \%$ increased compared to the values in December 2002 $\left(3.5 \times 10^{6} \mathrm{~kg}\right)$. Throughout the first three months in 2003 , the downward transport decreases by $2.45 \times 10^{7}$ $\mathrm{kg}$ the ozone mass inside the polar vortex, which offsets about $80 \%$ of the ozone mass transported by horizontal advection during the SSW events. As a result, the calculated net change of ozone mass due to dynamical processes (horizontal advection and vertical transport) is about $5.6 \times 10^{6} \mathrm{~kg}$ throughout the early 2003 . In order to separate the photochemical ozone production from dynamical ozone transport during early spring, a "passive ozone" run is performed and compared with the "reactive ozone" run. The result proves that most of the horizontal advection of ozone mass is caused by dynamics during the SSW events. However, after 1 March 2003, the enhanced downward ozone transport in the upper stratosphere (above $\sim 32 \mathrm{~km}$ ) should be attributed to the photochemical ozone production triggered by the springtime return of sunshine. Quantitative results show that only $\sim 55 \%$ of vertical ozone mass flux in February and March 2003 (as shown in Table 2) can be attributed to the variation in dynamical transport.

Stolarski and Douglass (1985) suggested that the temperature sensitivity of stratospheric ozone is dominated by that of the $\mathrm{NO}_{x}$ catalytic cycle for ozone chemical depletion. Figure 7 shows that the reaction rates of the $\mathrm{NO}_{x}$ catalytic cycle (based on JPL 0225 by Sanders et al., 2003) is enhanced by $40 \%-80 \%$ during the warming events (see panel e), resulting in prominent increases in chemical ozone depletion within the polar vortex (see panel d). Table 2 shows that, compared to the case in December $2002\left(2.0 \times 10^{5} \mathrm{~kg}\right)$, chemical ozone depletions are considerably enhanced during the warming events (especially in January and February 2003), causing a total of $2.5 \times 10^{6} \mathrm{~kg}$ of ozone mass destruction during the first three months in 2003. This chemical loss offsets about $44 \%$ of the ozone increase produced by dynamical processes (net effect of horizontal advection and vertical transport).

Table 2 also shows the temporal variation in the polar vortex ozone budget during the SSW events. For example, in December 2002, the ozone increase due to horizontal advection is comparable with the sum of vertical transport and chemical loss. As a result, the net increase in polar vortex ozone mass is only $3 \times 10^{5}$ $\mathrm{kg}$. By contrast, in January 2003, the ozone increase due to horizontal ozone advection is prominently larger than the effects of vertical transport and chemical 


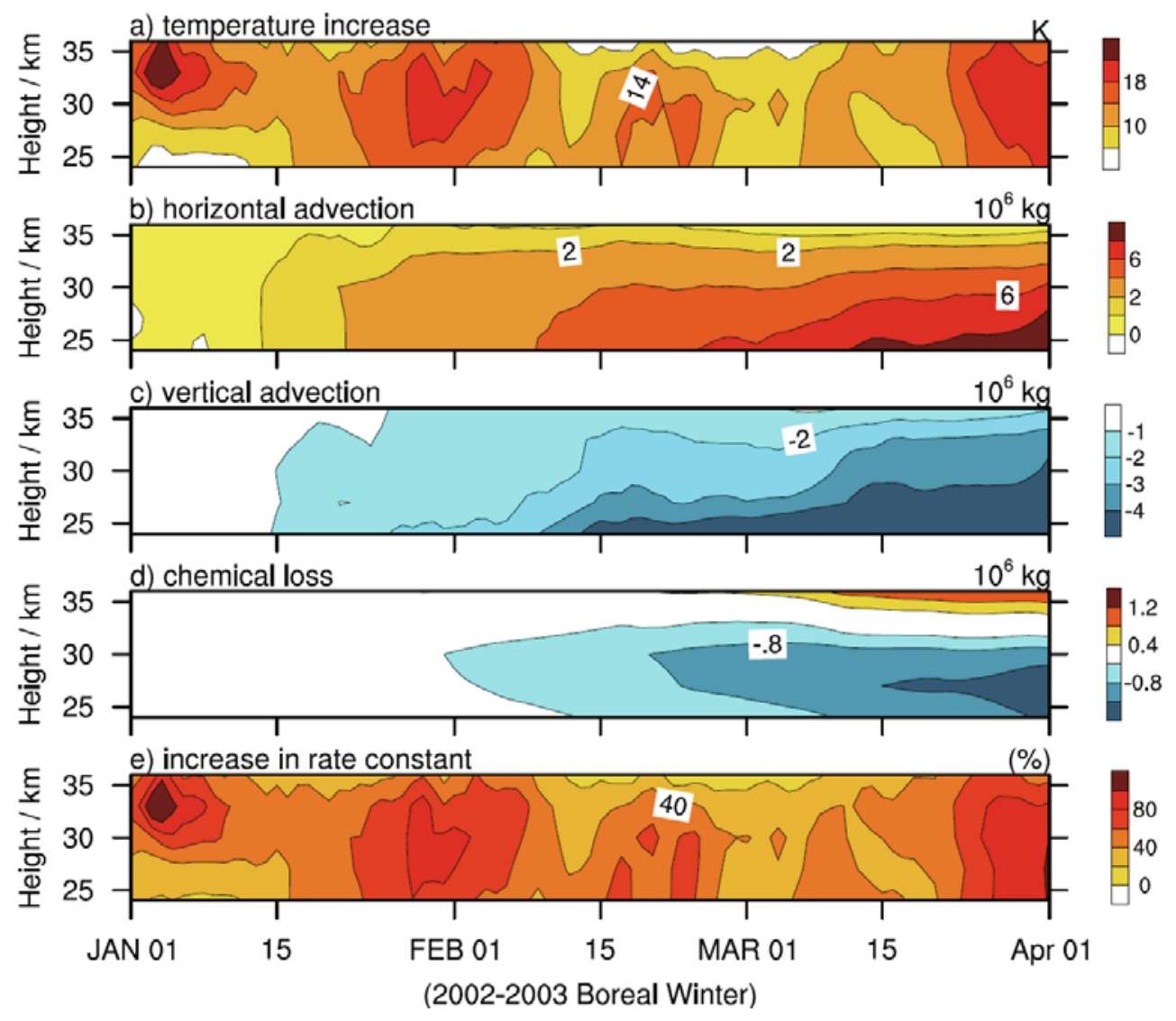

Fig. 7. Temperature increase (units: K) from ECMWF analysis and cumulated ozone budget (units: $10^{6} \mathrm{~kg}$ ) output from MOZART-3 inside the polar vortex throughout the winter: (a) increase in temperature relative to 15-31 December 2003 average; (b) ozone mass change by horizontal advection; (c) ozone mass change by vertical transport; (d) ozone mass change by chemical reactions; (e) variation (\%) of reaction rate constant of $\mathrm{NO}_{x}$ catalytic ozone depletion due to the temperature increase.

loss, resulting in a prominent increase in ozone mass $\left(3.2 \times 10^{6} \mathrm{~kg}\right.$ in total $)$. In February and March 2003, the increase in polar vortex ozone mass by horizontal transport is almost counteracted by vertical transport and chemical loss. Therefore, throughout the SSW events in early 2003 , a net increase of $3.2 \times 10^{6} \mathrm{~kg}$ of ozone mass results from both dynamics and chemistry.

\section{Summary and conclusions}

In this study, the MIPAS satellite data analysis and the MOZART-3 model simulation are applied to study the variations in ozone and $\mathrm{N}_{2} \mathrm{O}$ concentrations in the polar vortex during the warming Arctic winter 2002-2003. The result shows that the model calculation is fairly consistent with the measured ozone and $\mathrm{N}_{2} \mathrm{O}$ concentrations inside the polar vortex. The result also shows that, throughout the Arctic winter 20022003 , the variations in column ozone and $\mathrm{N}_{2} \mathrm{O}$ are very similar, suggesting that the dynamical processes play important roles for the increases of $\mathrm{N}_{2} \mathrm{O}$ and ozone in the polar vortex. However, it is also noted that the increase in column $\mathrm{N}_{2} \mathrm{O}$ is larger than that in column ozone, especially during March 2003. This implies that chemical processes are also important in controlling the ozone evolution. Thus, the detailed ozone budget analysis is needed.

The ozone budget analysis shows that (1) the horizontal transport of ozone into the polar vortex increases significantly due to the weakening of the vortex by planetary waves. This leads to increase in ozone mass by about $3.0 \times 10^{7} \mathrm{~kg}$ throughout early 2003 (January-March). This increase in ozone mass is 6.5 times larger than the value $\left(4.0 \times 10^{6} \mathrm{~kg}\right)$ in December 2002 when the polar vortex is stable. (2) The vertical advection also plays an important role in transporting the upper-stratospheric poor-ozone air downward into the middle stratosphere, producing a decrease in 
ozone mass during the SSW events. Throughout early 2003 , the vertical advection decreases ozone mass by about $2.45 \times 10^{7} \mathrm{~kg}$, which offsets about $80 \%$ of ozone mass transported by horizontal advection. However, a "passive ozone" experiment shows that only $\sim 55 \%$ of the vertical ozone mass flux in February and March 2003 can be attributed to the variation in dynamical transport. The enhanced downward ozone above $\sim 32$ $\mathrm{km}$ in the "reactive ozone" experiment should be attributed to the springtime photochemical ozone production. (3) During the SSW events, the calculated net change of ozone mass due to dynamical processes (horizontal advection and vertical transport) is about $5.6 \times 10^{6} \mathrm{~kg}$, which is more than twice as large as the mass $\left(2.5 \times 10^{6} \mathrm{~kg}\right)$ depleted by the $\mathrm{NO}_{x}$ catalytic cycle. (4) Throughout the three SSW periods, the chemical ozone depletion by the $\mathrm{NO}_{x}$ catalytic cycle is considerably enhanced as a result of the temperature increase. This chemical loss offsets about $44 \%$ of ozone increase produced by dynamical processes (net effect of horizontal advection and vertical transport). (5) Both MIPAS measurement and MOZART-3 calculation show a total increase of $26-28$ DU of column ozone (24-36 km) inside the polar vortex throughout the winter season (from 15 December 2002 to 31 March 2003). The increase in polar vortex ozone generally results from horizontal advection by planetary waves in January 2003. The MOZART-3 analysis also shows that, in other months (December 2002, February 2003), the ozone increase caused by horizontal advection is almost counteracted by the combined effects of vertical transport and chemical losses.

Acknowledgements. We thank WANG Yong for processing the MIPAS profiles. We thank Guy Brasseur and Douglass Kinnison from NCAR for kindly providing the MOZART-3 model. We also thank Stacy Walters for his patient help with interpreting the MOZART-3 outputs. This work was funded by the National Natural Science Foundation of China under Grant No. 40633015, the National Basic Research Program of China under Grant No. 2010CB428604, and the Dragon 2 Programme (ID: 5311). The National Center for Atmospheric Research is sponsored by the National Science Foundation of the USA. We also thank the ESA and MIPAS teams for providing MIPAS Level2 offline consolidated datasets. The meteorological analysis was provided by ECMWF.

\section{REFERENCES}

Brasseur, G. P., C. Granier, and S. Walters, 1990: Future changes in stratospheric ozone and the role of heterogeneous chemistry. Nature, 348, 626-628.

Cortesi, U., and Coauthors, 2007: Geophysical validation of MIPAS-ENVISAT operational ozone data. Atmo- spheric Chemistryand Physics, 7, 4807-4867.

Farman, J. C., B. G. Gardiner, and J. D. Shanklin, 1985: Large losses of total ozone in Antarctica reveal seasonal $\mathrm{ClO}_{x} / \mathrm{NO}_{x}$ interaction. Nature, 315, 207-210.

Flury, T., K. Hocke, A. Haefele, N. Kämpfer, and R. Lehmann, 2009: Ozone depletion, water vapor increase, and PSC generation at midlatitudes by the 2008 major stratospheric warming. J. Geophys. Res., 114, D18302, doi: 10.1029/2009JD011940.

Froidevaux, L., J. W. Waters, W. G. Read, L. S. Elson, D. A. Flower, and R. F. Jarnot, 1994: Global ozone observations from the UARS MLS: An overview of zonal-mean results. J. Atmos. Sci., 51, 2846-2866.

Fusco, A. C., and M. L. Salby, 1999: Interannual variations of total ozone and their relationship to variations of planetary wave activity. J. Climate, 12(6), 1619-1629.

Garcia, R. R., D. R. Marsh, D. E. Kinnison, B. A. Boville, and F. Sassi, 2007: Simulation of secular trends in the middle atmosphere, 1950-2003. J. Geophys. Res., 112, D09301, doi: 10.1029/2006JD007485.

Gettelman, A., D. E. Kinnison, T. J. Dunkerton, and G. P. Brasseur, 2004: Impact of monsoon circulations on the upper troposphere and lower stratosphere. J. Geophys. Res., 109, D22101, doi: 10.1029/2004JD004878.

Hauglustaine, D. A., G. R. Brasseur, S. Walters, P. J. Rasch, J.-F. Müller, L. K. Emmons, and M. A. Carroll, 1998: MOZART, a global chemical transport model for ozone and related chemical tracers 2 . Model results and evaluation. J. Geophys. Res., 103 (D21), 28291-28335.

Horowitz, L. W., and Coauthors, 2003: A global simulation of tropospheric ozone and related tracers: Description and evaluation of MOZART, version 2. J. Geophys. Res., 108(D24), 4784, doi: 10.1029/2002 JD002853.

Kinnison, D. E., and Coauthors, 2007: Sensitivity of chemical tracers to meteorological parameters in the MOZART-3 chemical transport model. J. Geophys. Res., 112, D20302, doi: 10.1029/2006JD007879.

Konopka, P., and Coauthors, 2007: Ozone loss driven by nitrogen oxides and triggered by stratospheric warmings can outweigh the effect of halogens. J. Geophys. Res., 112, D05105, doi: 10.1029/2006JD007064.

Lait, L. R., 1994: An alternative form for potential vorticity. J. Atmos. Sci., 51(12), 1754-1759.

Liu, C., Y. Liu, Z. Cai, S. Gao, D. Lü, and E. Kyrölä, 2009a: A Madden-Julian Oscillation-triggered record ozone minimum over the Tibetan Plateau in December 2003 and its association with stratospheric "lowozone pockets". Geophys. Res. Lett., 36, L15830, doi: 10.1029/2009GL039025.

Liu, C., H. Wang, and Y. Liu, 2009b: Polar stratospheric methane and water vapor during the boreal 20032004 stratospheric sudden warming event. Progress in Natural Science, 19(4), 425-433. (in Chinese)

Liu, Y., C. Liu, H. Wang, X. Tie, S. Gao, D. E. Kinnison, and G. P. Brasseur, 2009c: Atmospheric tracers 
during the 2003-2004 stratospheric warming event and impact of ozone intrusions in the troposphere. Atmospheric Chemistry and Physics, 9, 2157-2170.

Manney, G. L., and Coauthors, 1994: Chemical depletion of ozone in the Arctic lower stratosphere during winter 1992-93. Nature, 370, 429-434.

Manney, G. L., L. Froidevaux, M. L. Santee, N. J. Livesey, J. L. Sabutis, and J. W. Waters, 2003: Variability of ozone loss during Arctic winter (1991-2000) estimated from UARS Microwave Limb Sounder measurements. J. Geophys. Res., 108(D4), 4149, doi: 10.1029/2002JD002634.

Manney, G. L., K. Kruger, J. L. Sabutis, S. A. Sena, and S. Pawson, 2005: The remarkable 2003-2004 winter and other recent warm winters in the Arctic stratosphere since the late 1990s. J. Geophys. Res., 110, D04107, doi: 10.1029/2004JD005367.

Matsuno, T., 1971: A dynamical model of the stratospheric sudden warming. J. Atmos. Sci., 28, 14791494.

McIntyre, M. E., and T. N. Palmer, 1983: Breaking planetary waves in the stratosphere. Nature, 305, 593600.

Pan, L. L., J. C. Wei, D. E. Kinnison, R. R. Garcia, D. J. Wuebbles, and G. P. Brasseur, 2007: A set of diagnostics for evaluating chemistry-climate models in the extratropical tropopause region. J. Geophys. Res., 112, D09316, doi: 10.1029/2006 JD007792.

Park, M., W. J. Randel, D. E. Kinnison, R. R. Garcia, and W. Choi, 2004: Seasonal variation of methane, water vapor, and nitrogen oxides near the tropopause: Satellite observations and model simulations. J. Geophys. Res., 109, D03302, doi: 10.1029/ 2003JD003706.

Randall, C. E., and Coauthors, 1995: Preliminary results from POAM II: Stratospheric ozone at high northern latitudes. Geophys. Res. Lett., 22(20), 2733-2736, doi: 10.1029/95GL02649.

Randall, C. E., and Coauthors, 2005: Stratospheric effects of energetic particle precipitation in 2003-2004. Geophys. Res. Lett., 32(5), L05802, doi: 10.1029/ 2004GL022003.

Raspollini, P., and Coauthors, 2006: MIPAS level 2 operational analysis. Atmospheric Chemistry and Physics, 6, 5605-5630.

Rex, M., R. J. Salawitch, P. von der Gathen, N. R. P. Harris, M. P. Chipperfield, and B. Naujokat, 2004: Arctic ozone loss and climate change. Geophys. Res. Lett., 31, L04116, doi: 10.1029/2003GL018844.

Sanders, S. P., and Coauthors, 2003: Chemical kinetics and photochemical data for use in atmospheric studies. JPL Publication 02-25, 334pp.

Scherhag, R., 1952: Die explosionsartigen stratosphärener warmungen des spätwinters 1951-1952 (The explsion-like stratospheric warmings of the late winter 1951/1952). Berichte Deutscher Wetterdienst in der US-Zone, 6(38), 51-63.

Schmidt, H., and Coauthors, 2006: The HAMMONIA chemistry climate model: Sensitivity of the mesospause region to the 11-year solar cycle and $\mathrm{CO}_{2}$ doubling. J. Climate, 19, 3903-3931.

Sassi, F., B. A. Boville, D. Kinnison, and R. R. Garcia, 2005: The effects of interactive ozone chemistry on simulations of the middle atmosphere. Geophys. Res. Lett., 32, L07811, doi: 10.1029/2004GL022131.

Solomon, S., 1990: Progress towards a quantitative understanding of Antarctic ozone depletion. Nature, 347, 347-354.

Solomon, S., P. J. Crutzen, and R. G. Roble, 1982: Photochemical coupling between the thermosphere and the lower atmosphere: 1 . Odd nitrogen from 50 to 120 km. J. Geophys. Res., 87, 7206-7220.

Stolarski, R. S., and A. R. Douglass, 1985: Parameterization of the photochemistry of stratospheric ozone including catalytic loss processes. J. Geophys. Res., 90(D6), 10709-10718.

Streibel, M., and Coauthors, 2006: Chemical ozone loss in the Arctic winter 2002/2003 determined with Match. Atmospheric Chemistry and Physics, 5, 4311-4333.

Tie, X., and G. P. Brasseur, 1995: The response of stratospheric ozone to volcanic eruptions: Sensitivity to atmospheric chlorine load. Geophys. Res. Lett., 22, 3035-3038.

Tie, X., and G. P. Brasseur, 1996: The importance of heterogeneous bromine chemistry in the lower stratosphere. Geophys. Res. Lett., 23, 2505-2508.

Tilmes, S., R. Müller, J.-U. Groo $\beta$, M. Höpfner, G. C. Toon, and J. M. Russell, 2003: Very early chlorine activation and ozone loss in the Arctic winter 2002-2003. Geophys. Res. Lett., 30(23), 2201, doi: 10.1029/2003GL018079.

Vigouroux, C., and Coauthors, 2007: Comparisons between ground-based FTIR and MIPAS $\mathrm{N}_{2} \mathrm{O}$ and $\mathrm{HNO}_{3}$ profiles before and after assimilation in BASCOE. Atmospheric Chemistry and Physics, 7, 377396.

Zou, H., and Coauthors, 2005: Total ozone variation between $50^{\circ}$ and $60^{\circ} \mathrm{N}$. Geophys. Res. Lett., 32, L23812, doi: 10.1029/2005GL024012. 